\title{
Effect of culture media and conditions on polyunsaturated fatty acids production by Mortierella alpina
}

\author{
Hung-Der Jang ${ }^{\text {a }}$, Yuh-Yih Lin ${ }^{c}$, Shang-Shyng Yang ${ }^{\text {b,c,* }}$ \\ a Department of Food Science, Yuanpei University of Science and Technology, Hsinchu 300, Taiwan \\ ${ }^{\mathrm{b}}$ Department of Biochemical Science and Technology, National Taiwan University, Taipei 10617, Taiwan \\ ${ }^{\mathrm{c}}$ Institute of Microbiology and Biochemistry, National Taiwan University, Taipei 10617, Taiwan
}

Received 12 January 2004; received in revised form 15 December 2004; accepted 31 December 2004

Available online 8 March 2005

\begin{abstract}
To improve the polyunsaturated fatty acid (PUFA) production by Mortierella, culture media and conditions were investigated. M. alpina ATCC 32222 had the highest yield of arachidonic acid, $\gamma$-linolenic acid and linoleic acid among 11 test microbes. Soluble starch at $10 \%$ and the mixture of $\mathrm{KNO}_{3}$ and yeast extract at $2: 1(\mathrm{w} / \mathrm{w})$ was the best carbon and nitrogen sources for arachidonic acid and total PUFAs production, respectively. The optimal $\mathrm{C} / \mathrm{N}$ ratio ranged from 5.1 to 9.0. Each gram of carbon produced 17.4 mg of linoleic acid, $17.0 \mathrm{mg}$ of $\gamma$-linolenic acid, $103.0 \mathrm{mg}$ of arachidonic acid and $194.2 \mathrm{mg}$ of total PUFAs at $20^{\circ} \mathrm{C}$, while it yielded $21.4 \mathrm{mg}$ of linoleic acid, $25.6 \mathrm{mg}$ of $\gamma$-linolenic acid, $2.6 \mathrm{mg}$ of $\gamma$-linolenic acid, $110.3 \mathrm{mg}$ of arachidonic acid, $4.3 \mathrm{mg}$ of eicosapentaenoic acid and $218.4 \mathrm{mg}$ of total PUFAs at $12{ }^{\circ} \mathrm{C}$. A high degree of unsaturation was found at low temperature incubation. Linseed oil supplementation $(1 \%, \mathrm{w} / \mathrm{v})$ increased the PUFAs production and each gram of carbon produced $403.4 \mathrm{mg}$ of $\alpha$-linolenic acid, $123.1 \mathrm{mg}$ of arachidonic acid, $33.6 \mathrm{mg}$ of eicosapentaenoic acid, $1.68 \mathrm{mg}$ of docosahexaenoic acid and $943.2 \mathrm{mg}$ of total PUFAs. From the optimization of culture media and conditions, PUFAs production increased from $30 \%$ to 5 times that was optimal for practical use.
\end{abstract}

(c) 2005 Elsevier Ltd. All rights reserved.

Keywords: Mortierella alpina; Polyunsaturated fatty acid; Soluble starch; Linseed oil; C/N ratio; Degree of unsaturation

\section{Introduction}

The $\omega-3$ and $\omega-6$ series of polyunsaturated fatty acids are identified as potential food additives or pharmaceuticals for their biological activities. The PUFAs could be used in treatment of heart and circulatory disorders, cancer or participation in the inflammatory reaction (Braden and Caroll, 1986; Dyerberg, 1986; Willett, 1993; Demaison and Moreau, 2002; Gil, 2002). Many

\footnotetext{
* Corresponding author. Address: Department of Biochemical Science and Technology, National Taiwan University, Taipei 10617, Taiwan. Tel.: +886 2 23621519; fax: 886223679827 .

E-mail address: ssyang@ntu.edu.tw (S.-S. Yang).
}

species of the genus Mortierella have been found to yield exceptionally high amount of PUFAs depending upon the fermentation media and culture conditions (Yamada et al., 1987; Hansson and Dostalek, 1988; Shimizu et al., 1989; Sajbidor et al., 1990; Bajpai et al., 1991a,b,c; Kendrick and Ratledge, 1992; Jareokitmongkol et al., 1993; Lindberg and Molin, 1993; Jang and Yang, 1998; Jang et al., 2000; Yu et al., 2003).

The extensive research and production of PUFA by the fungus Mortierella in submerged culture was carried out over the past several years. However, emphasis is put on screening for more efficient strains, using suitable substrates and cultivating the strains at the optimum conditions to achieve the maximal PUFAs yield (Bajpai et al., 1991a,b,c; Li and Ward, 1994; Certik and 
Shimizu, 1999; Koike et al., 2001). Being economically competitive, the producing strains, culture media and conditions of Mortierella for PUFAs production were examined in this study.

\section{Methods}

\subsection{Test organism}

Mortierella alpina ATCC 32222 was purchased from the American Type Culture Collection, while M. alpina CCRC 32365, M. alpina CCRC 32738, M. elongata CCRC 32709, M. humicola CCRC 31720, M. isabellina CCRC 31721, M. isabellina CCRC 31847, M. nana CCRC 31722, M. ramanniana CCRC 31391, M. ramanniana CCRC 31723 and M. ramanniana CCRC 31809 were purchased from the Bioresource Collection and Research Center of Food Industry Research and Development Institute, Hsinchu, Taiwan. All microorganisms were used for the production of PUFAs.

\subsection{Culture media and conditions}

Mortierella was grown at $20{ }^{\circ} \mathrm{C}$ in a membrane culture containing $\left(\mathrm{mg} \mathrm{I}^{-1}\right)$ : glucose, 10; yeast extract, 5 and agar, 20 at $\mathrm{pH}$ 6.5. Mycelia were harvested from membrane culture and blended with a micro-Waring blender for mycelial suspension. Submerged basal medium contained $\left(\mathrm{mg} \mathrm{I}^{-1}\right)$ soluble starch, 20; Bacto yeast extract, 5; $\mathrm{KNO}_{3}, 10 ; \mathrm{KH}_{2} \mathrm{PO}_{4}, 1$ and $\mathrm{MgSO}_{4} \cdot 7 \mathrm{H}_{2} \mathrm{O}$, 0.25 at $\mathrm{pH}$ 6.5. The broth was inoculated with $5 \%$ (v/v) mycelial suspension, shaken at $200 \mathrm{rev} \mathrm{min}^{-1}$ and incubated at $20^{\circ} \mathrm{C}$ for $2-10$ days. Each $\mathrm{ml}$ of mycelial suspension contained 1.0-1.5 $\times 10^{6}$ mycelial fragments.

\subsection{Cell dry weight determination}

Mycelia were harvested from culture broth by suction filtration through Whatman No. 4 filter paper. Cell dry weight was determined by washing the mycelia with distilled water twice and then freeze-dried at $-50{ }^{\circ} \mathrm{C}$ for $24 \mathrm{~h}$ to get a constant weight. The dried mycelia were grounded into a fine powder for following extraction by organic solvents. The lipid content of grounded powder was extracted and determined the homogeneity.

\subsection{Lipid extraction}

Extraction of lipids from mycelia was performed according to the modified procedure of Bligh and Dyer (1959). Lipids were extracted with a 5 times volume of chloroform/methanol $(2: 1, \mathrm{v} / \mathrm{v})$ by an ultrasonicator for $2 \mathrm{~h}$, filtered through Whatman No. 1 filter paper and concentrated by rotatory evaporator (Buchi, Swiss) at $50{ }^{\circ} \mathrm{C}$.

\subsection{Fatty acid analysis}

The residue of extracted lipid was dissolved in $1 \mathrm{ml}$ of $0.5 \mathrm{M} \mathrm{KOH}-\mathrm{MeOH}$ solution, and methylated by $1 \mathrm{ml}$ of $14 \%(\mathrm{w} / \mathrm{v}) \mathrm{BF}_{3}$ in $\mathrm{MeOH}$. The methylated fatty acids were separated from the aqueous layer by adding saturated $\mathrm{NaCl}$ and anhydrous $\mathrm{Na}_{2} \mathrm{SO}_{4}$, and then dissolving in n-hexane. PUFA content was determined by using gas chromatography GC-8A (Shimadzu Co., Japan) equipped with a $5 \%$ diethylene glycol succinate $(60 / 80$ mesh) and $1 \% \mathrm{H}_{3} \mathrm{PO}_{4}$ packed glass column $(0.26 \mathrm{~mm}$ i.d. $\times 2 \mathrm{~m}$ ) and a flame ionization detector. Nitrogen was used as the carrier gas. The column temperature was programmed from 190 to $200{ }^{\circ} \mathrm{C}$ with an increasing rate of $4{ }^{\circ} \mathrm{C} \min ^{-1}$. Injection port and detector temperatures were maintained at $230{ }^{\circ} \mathrm{C}$. Methyl esters of palmitic acid, palmitoleic acid, stearic acid, oleic acid, linoleic acid, $\alpha$-linolenic acid, $\gamma$-linolenic acid, arachidonic acid, eicosapentaenoic acid, and docosahexaenoic acid were used as standard for fatty acid identification and quantitation. Methyl pentadecanoate was added as an internal standard (Jang et al., 2000).

\subsection{Effect of culture conditions on PUFAs production}

\subsubsection{Incubation temperature, carbon source and oil supplement}

The basal medium was incubated with orbital shaking at $12-28^{\circ} \mathrm{C}$ for 7 days for temperature effect. Soluble starch in the basal medium was replaced by galactose, glucose, maltose and glycerol and incubated at $20{ }^{\circ} \mathrm{C}$ for 7 days for carbon source effect. The effect of carbon source concentration was used $0.0-12.0 \%$ of soluble starch or $0.0-10.0 \%$ of glucose. The basal medium supplemented with $1 \%$ corn oil, lard oil, linseed oil, peanut oil, soybean oil and sunflower oil was used for oil amendment test. The effect of soybean oil concentration was studied from $0.0 \%$ to $1.5 \%$. The effect of carbon source and soybean oil was studied using $2.0-8.0 \%$ of glucose or soluble starch as carbon source with $1.0 \%$ soybean oil supplementation.

\subsubsection{Nitrogen source and $C / N$ ratio}

Nitrogen source in the basal medium was replaced by $1.5 \%$ of $\mathrm{NH}_{4} \mathrm{NO}_{3},\left(\mathrm{NH}_{4}\right)_{2} \mathrm{SO}_{4}, \mathrm{KNO}_{3}, \mathrm{NaNO}_{3}$, urea, yeast extract and the different ratios of a mixture of $\mathrm{KNO}_{3}$ and yeast extract (w/w) from 1:3 to $3: 1$. The effect of $\mathrm{C} / \mathrm{N}$ ratio was studied with $2 \%$ of soluble starch as carbon source adjusting the ratio of different nitrogen sources and the mixture of $\mathrm{KNO}_{3}$ and yeast extract at 2:1 (w/w) from 2.5 to 48.3 .

\subsection{Chemical analysis}

$\mathrm{pH}$ was measured directly with $\mathrm{pH}$ meter. Total nitrogen was determined by a modified Kjeldahl method 
(Yang et al., 1991). The protein content was calculated as 6.25 times the total nitrogen content. Degree of unsaturation of fatty acids was calculated as the sum of the product of concentration $(\%, w / w)$ and the number of unsaturated double bonds of each fatty acid as follows (Chen and Chang, 1994): Degree of unsaturation $=1$ $(\%$ of monoene $)+2(\%$ of diene $)+3(\%$ of triene $)+4$ $(\%$ of tetraene $)+5(\%$ of pentaene $)+6(\%$ of hexaene $)$.

\subsection{Statistical analysis}

Treatments were done in triplicate, and experimental data was subjected to analysis of variance and Duncan's multiple range test $(p=0.05)$ using the Statistical Analysis System (SAS Institute, 2002).

\section{Results and discussion}

\subsection{Qualitative and quantitative determination of fatty acid}

In gas chromatograph, the retention times of test fatty acids increase with increasing number of carbon atoms and double bonds. Palmitic acid and palmitoleic acid had shorter retention time, whereas docosahexaenoic acid had a longer one. The concentration of fatty acids $(X)$ and the sum of absorbance $(Y)$ at a specific retention time had a linear correlation. In the concentrations between 0 and $2000 \mathrm{mg}^{-1}$, the equation and correlation coefficient $(r)$ were $Y=95.66 X-8102$ and 0.9993, $Y=90.92 X+10674$ and 0.9994, and $Y=$ $86.71 X-9134$ and 0.9991 for arachidonic acid, eicosapentaenoic acid, and docosahexaenoic acid, respectively.

\subsection{Effect of test organism on PUFAs production}

Polyunsaturated fatty acid production with different species of Mortierella is shown in Table 1. M. alpina
ATCC 32222, M. alpina CCRC 32738 and M. alpina CCRC 32365 had high arachidonic acid production, M. elongata CCRC 32709 and M. isabellina CCRC 31721 had low yield, and the other test strains had undetectable levels. In addition, M. alpina ATCC 32222 had the highest arachidonic acid and total PUFAs production. There were significant differences among the test species in linoleic acid, $\gamma$-linolenic acid, $\alpha$-linolenic acid and arachidonic acid production. Therefore $M$. alpina ATCC 32222 was chosen for further study.

\subsection{Effect of culture temperature and cultivation period on PUFAs production}

Microbial growth had a high rate between 15 and $25^{\circ} \mathrm{C}$, and the value decreased dramatically when the incubation temperature was higher than $25^{\circ} \mathrm{C}$ or lower than $15^{\circ} \mathrm{C}$. The effect of incubation temperature on biomass and PUFAs production is presented in Table 2. Biomass production was high at $20^{\circ} \mathrm{C}$, followed by 15 and $12{ }^{\circ} \mathrm{C}$, and $25^{\circ} \mathrm{C}$ was the least. The growth of $M$. alpina at $20^{\circ} \mathrm{C}$ had a lag phase of $34 \mathrm{~h}, \log$ phase between 72 and $120 \mathrm{~h}$, stationary phase between 120 and $168 \mathrm{~h}$ and decline phase after $192 \mathrm{~h}$. The $\mathrm{pH}$ of culture broth increased from 6.0 to 7.1 for $168 \mathrm{~h}$ incubation, and then decreased gradually to 5.9 after $240 \mathrm{~h}$. The time for maximum yield was $72 \mathrm{~h}$ for $\gamma$-linolenic acid, $120 \mathrm{~h}$ for linoleic acid and $144 \mathrm{~h}$ for total PUFAs and arachidonic acid. PUFAs are primary metabolites and the yield was associated with the cell growth. The production of PUFAs decreased gradually in prolonged cultivation due to cell lysis (Yamada et al., 1987; Bajpai and Bajpai, 1992). Time for maximum yield of PUFAs depends on the kind of fatty acid. $\gamma$-Linolenic acid and linoleic acid were synthesized prior to arachidonic acid and eicosapentaenoic acid. Yamada et al. (1987) and Bajpai et al. (1991a) also reported that M. alipina IS-4 and ATCC 32222 had their maximal production at 4and 3-days incubation, respectively. $\omega-3$ and $\omega-6$ series

Table 1

PUFAs production of test organisms

\begin{tabular}{|c|c|c|c|c|c|}
\hline Test strain & $\mathrm{LA}\left(\mathrm{mg}^{-1}\right)$ & GLA $\left(\mathrm{mg}^{-1}\right)$ & $\operatorname{ALA}\left(\mathrm{mg} \mathrm{l}^{-1}\right)$ & $\mathrm{AA}\left(\mathrm{mg} \mathrm{l}^{-1}\right)$ & Total PUFAs $\left(\mathrm{mg} \mathrm{l}^{-1}\right)$ \\
\hline M. alpina ATCC 32222 & $50.0 \pm 2.6^{\mathrm{a}}$ & $17.7 \pm 2.4^{\mathrm{a}}$ & $4.9 \pm 2.6^{\mathrm{b}, \mathrm{c}}$ & $356.8 \pm 10.4^{\mathrm{a}}$ & $429.4 \pm 9.0^{\mathrm{a}}$ \\
\hline M. alpina CCRC 32738 & $10.7 \pm 0.6^{\mathrm{b}}$ & $5.7 \pm 0.6^{\mathrm{b}}$ & $7.7 \pm 1.4^{\mathrm{a}, \mathrm{b}}$ & $56.3 \pm 5.0^{\mathrm{b}}$ & $80.4 \pm 5.1^{\mathrm{b}}$ \\
\hline M. alpina CCRC 32365 & $7.0 \pm 1.4^{\mathrm{c}}$ & $5.3 \pm 0.2^{\mathrm{b}, \mathrm{c}}$ & $8.0 \pm 1.5^{\mathrm{a}, \mathrm{b}}$ & $25.4 \pm 2.1^{\mathrm{c}}$ & $45.5 \pm 4.3^{\mathrm{c}}$ \\
\hline M. elongata CCRC 32709 & $7.0 \pm 0.3^{\mathrm{c}}$ & $1.8 \pm 0.3^{\mathrm{d}, \mathrm{e}}$ & $1.0 \pm 0.4^{\mathrm{d}}$ & $8.5 \pm 1.1^{\mathrm{d}}$ & $18.2 \pm 1.7^{\mathrm{d}}$ \\
\hline M. isabellina CCRC 31721 & ND & ND & ND & $1.3 \pm 0.1^{\mathrm{e}}$ & $1.3 \pm 0.1^{\mathrm{e}}$ \\
\hline M. humicola CCRC 31720 & $13.0 \pm 0.2^{\mathrm{b}}$ & $6.0 \pm 0.0^{\mathrm{b}}$ & $0.7 \pm 1.2^{\mathrm{d}}$ & ND & $29.6 \pm 1.5^{\mathrm{d}}$ \\
\hline M. ramanniana CCRC 31391 & $2.2 \pm 0.1^{\mathrm{d}}$ & $2.1 \pm 0.2^{\mathrm{d}, \mathrm{e}}$ & $3.4 \pm 1.3^{\mathrm{c}, \mathrm{d}}$ & ND & $27.0 \pm 1.6^{\mathrm{d}}$ \\
\hline M. isabellina CCRC 31847 & $9.9 \pm 0.6^{\mathrm{b}, \mathrm{c}}$ & $4.3 \pm 0.4^{\mathrm{b}, \mathrm{c}, \mathrm{d}}$ & $3.9 \pm 1.5^{\mathrm{c}, \mathrm{d}}$ & ND & $18.0 \pm 1.6^{\mathrm{d}}$ \\
\hline M. ramanniana CCRC 31809 & $3.2 \pm 0.2^{\mathrm{d}}$ & $2.8 \pm 0.2^{\mathrm{d}, \mathrm{e}}$ & $3.1 \pm 0.4^{\mathrm{c}, \mathrm{d}}$ & ND & $9.1 \pm 0.8^{\mathrm{e}}$ \\
\hline M. ramanniana CCRC 31723 & $2.3 \pm 0.1^{\mathrm{d}}$ & $1.3 \pm 0.1^{\mathrm{e}}$ & $1.3 \pm 1.1^{\mathrm{d}}$ & ND & $4.8 \pm 1.0^{\mathrm{e}}$ \\
\hline M. nana CCRC 31722 & ND & ND & ND & ND & ND \\
\hline
\end{tabular}

The concentrations of fatty acid are expressed as mean \pm standard deviation of triplicate experiments. Values in the same column that do not share the same alphabetic superscript are significantly different at $5 \%$ levels according to Duncan's multiple range tests. The basal medium was $2.0 \%$ of soluble starch as carbon source at initial $\mathrm{pH} 6.0$ and incubated at $20^{\circ} \mathrm{C}$ for 7 days. ND: under detection, PUFAs: polyunsaturated fatty acids, LA: linoleic acid, GLA: $\gamma$-linolenic acid, ALA: $\alpha$-linolenic acid, AA: arachidonic acid. 
Table 2

Effect of incubation temperature on biomass and PUFAs production of M. alpina ATCC 32222

\begin{tabular}{|c|c|c|c|c|c|c|c|c|c|}
\hline Temperature $\left({ }^{\circ} \mathrm{C}\right)$ & Cell dry weight $\left(\mathrm{g}^{-1}\right)$ & LA $\left(m g 1^{-1}\right)$ & GLA $\left(\mathrm{mg} \mathrm{l}^{-1}\right)$ & $\operatorname{ALA}\left(\mathrm{mg} \mathrm{l}^{-1}\right)$ & $\mathrm{AA}\left(\mathrm{mg} \mathrm{l}^{-1}\right)$ & EPA $\left(\mathrm{mg} \mathrm{l}^{-1}\right)$ & Others $\left(\mathrm{mg} \mathrm{l}^{-1}\right)$ & Total PUFAs $\left(\mathrm{mg} \mathrm{l}^{-1}\right)$ & $\Delta$ \\
\hline 12 & $6.2 \pm 0.2^{\mathrm{b}}$ & $\begin{array}{l}131.4 \pm 3.4^{\mathrm{a}} \\
(8.01 \pm 0.19 \%)\end{array}$ & $\begin{array}{c}164.9 \pm 5.2^{\mathrm{a}} \\
(10.06 \pm 0.24 \%)\end{array}$ & $\begin{array}{c}c 20.8 \pm 1.3^{\mathrm{a}} \\
(1.27 \pm 0.07 \%)\end{array}$ & $\begin{array}{c}882.4 \pm 47.5^{\mathrm{a}} \\
(53.81 \pm 0.25 \%)\end{array}$ & $\begin{array}{c}34.4 \pm 6.4^{\mathrm{a}} \\
(2.10 \pm 0.12 \%)\end{array}$ & $\begin{array}{c}406.1 \pm 10.3^{\mathrm{a}} \\
(24.76 \pm 0.34 \%)\end{array}$ & $\begin{array}{l}1627.0 \pm 15.4^{\mathrm{a}} \\
(100 \%)\end{array}$ & $3.89 \pm 0.01^{\mathrm{a}}$ \\
\hline 15 & $6.3 \pm 0.3^{\mathrm{b}}$ & $\begin{array}{l}129.9 \pm 8.3^{\mathrm{a}} \\
(8.01 \pm 0.11 \%)\end{array}$ & $\begin{array}{l}161.0 \pm 2.0^{\mathrm{a}} \\
(9.93 \pm 0.14 \%)\end{array}$ & $\begin{array}{l}17.4 \pm 1.0^{\mathrm{b}} \\
(1.07 \pm 0.17 \%)\end{array}$ & $\begin{array}{c}871.9 \pm 10.5^{\mathrm{a}} \\
(53.76 \pm 0.49 \%)\end{array}$ & $\begin{array}{l}30.6 \pm 5.1^{\mathrm{a}} \\
(1.89 \pm 0.07 \%)\end{array}$ & $\begin{array}{c}411.2 \pm 11.2^{\mathrm{a}} \\
(25.35 \pm 1.04 \%)\end{array}$ & $\begin{array}{l}1621.9 \pm 15.6^{\mathrm{a}} \\
(100 \%)\end{array}$ & $3.88 \pm 0.01^{\mathrm{a}}$ \\
\hline 20 & $7.2 \pm 0.3^{\mathrm{a}}$ & $\begin{array}{l}99.2 \pm 0.8^{\mathrm{b}} \\
(6.83 \pm 0.06 \%)\end{array}$ & $\begin{array}{l}96.3 \pm 6.3^{\mathrm{b}} \\
(6.63 \pm 0.03 \%)\end{array}$ & ND & $\begin{aligned} 826.3 & \pm 4.2^{\mathrm{b}} \\
(56.91 & \pm 0.16 \%)\end{aligned}$ & $\begin{aligned} 8.2 & \pm 2.8 \mathrm{~b} \\
(0.57 & \pm 0.18 \%)\end{aligned}$ & $\begin{array}{c}422.0 \pm 10.6^{\mathrm{a}} \\
(29.06 \pm 0.06 \%)\end{array}$ & $\begin{array}{l}1466.4 \pm 6.2^{b} \\
(100 \%)\end{array}$ & $3.84 \pm 0.01^{\mathrm{b}}$ \\
\hline 25 & $6.0 \pm 0.3^{\mathrm{b}}$ & $\begin{array}{l}77.0 \pm 5.1^{\mathrm{c}} \\
(6.25 \pm 0.41 \%)\end{array}$ & $\begin{array}{l}62.2 \pm 3.5^{\mathrm{c}} \\
\left(5.05 \pm 0.12^{\%} \%\right)\end{array}$ & ND & $\begin{array}{c}630.6 \pm 21.1^{\mathrm{c}} \\
(51.22 \pm 1.08 \%)\end{array}$ & ND & $\begin{array}{l}461.4 \pm 15.4^{\mathrm{a}} \\
\left(37.48 \pm 0.72^{\circ} \%\right)\end{array}$ & $\begin{array}{l}1231.2 \pm 8.5^{\mathrm{c}} \\
(100 \%)\end{array}$ & $3.76 \pm 0.01^{\mathrm{c}}$ \\
\hline
\end{tabular}

The concentrations of fatty acid are expressed as mean \pm standard deviation ( $\%$ of total fatty acids) of triplicate experiments. Values in the same column that do not share the same alphabetic superscript are significantly different at $5 \%$ levels according to Duncan's multiple range tests. The basal medium was $2.0 \%$ of soluble starch as carbon source at initial pH 6.0 and incubated at $20{ }^{\circ} \mathrm{C}$ for 7 days. EPA: eicosapentaenoic acid. Others: the difference between total PUFAs and state fatty acid in the table. $\Delta$ : degree of unsaturation. Same abbreviations as described in Table 1.

Table 3

Effect of carbon source on biomass and PUFAs production of M. alpina ATCC 32222

\begin{tabular}{|c|c|c|c|c|c|c|c|c|}
\hline Carbon source & Cell dry weight $\left(\mathrm{g}^{-1}\right)$ & $\mathrm{LA}\left(\mathrm{mg} \mathrm{l}^{-1}\right)$ & GLA $\left(\mathrm{mg} \mathrm{l}^{-1}\right)$ & $\operatorname{ALA}\left(\mathrm{mg} \mathrm{l}^{-1}\right)$ & AA $\left(\mathrm{mg} \mathrm{l}^{-1}\right)$ & Others $\left(\mathrm{mg}^{-1}\right)$ & Total PUFAs $\left(\mathrm{mg}^{-1}\right)$ & $\Delta$ \\
\hline Soluble starch & $7.2 \pm 0.4^{\mathrm{a}}$ & $\begin{array}{l}99.2 \pm 0.4^{\mathrm{a}} \\
(6.89 \pm 0.04 \%)\end{array}$ & $\begin{array}{l}96.3 \pm 6.5^{\mathrm{a}} \\
(6.68 \pm 0.64 \%)\end{array}$ & ND & $\begin{array}{l}826.3 \pm 4.3^{\mathrm{a}} \\
\left(57.37 \pm 0.42^{\%} \%\right)\end{array}$ & $\begin{array}{l}418.6 \pm 9.1^{\mathrm{a}} \\
(29.06 \pm 0.06 \%)\end{array}$ & $\begin{array}{l}1440.5 \pm 20.8^{\mathrm{a}} \\
(100 \%)\end{array}$ & $3.87 \pm 0.01^{\mathrm{a}}$ \\
\hline Glucose & $7.5 \pm 1.1^{\mathrm{a}}$ & $\begin{array}{l}58.8 \pm 0.1^{\mathrm{c}} \\
(4.58 \pm 0.01 \%)\end{array}$ & $\begin{array}{c}69.9 \pm 3.5^{\mathrm{b}} \\
(5.45 \pm 0.43 \%)\end{array}$ & ND & $\begin{array}{c}673.1 \pm 14.2^{\mathrm{b}} \\
\left(52.45 \pm 1.77^{\circ} \%\right)\end{array}$ & $\begin{array}{l}481.3 \pm 7.4^{\mathrm{a}} \\
(37.51 \pm 6.31 \%)\end{array}$ & $\begin{array}{l}1283.2 \pm 17.2^{\mathrm{b}} \\
(100 \%)\end{array}$ & $3.80 \pm 0.05^{\mathrm{a}}$ \\
\hline Glycerol & $6.5 \pm 0.5^{\mathrm{b}}$ & $\begin{array}{c}42.4 \pm 2.1^{\mathrm{d}} \\
(5.56 \pm 0.31 \%)\end{array}$ & ND & $\begin{array}{l}22.6 \pm 2.4 \\
(2.96 \pm 0.37 \%)\end{array}$ & $\begin{array}{c}595.4 \pm 10.8^{\mathrm{c}} \\
(78.00 \pm 1.63 \%)\end{array}$ & $\begin{array}{c}102.8 \pm 4.9^{\mathrm{c}} \\
(13.47 \pm 1.79 \%)\end{array}$ & $\begin{array}{l}763.3 \pm 16.5^{\mathrm{c}} \\
(100 \%)\end{array}$ & $3.44 \pm 0.03^{\mathrm{b}}$ \\
\hline Galactose & $5.1 \pm 0.4^{\mathrm{c}}$ & $\begin{array}{c}91.8 \pm 1.4^{\mathrm{a}} \\
(19.04 \pm 0.37 \%)\end{array}$ & $\begin{array}{l}112.7 \pm 3.3^{\mathrm{a}} \\
(23.36 \pm 0.87 \%)\end{array}$ & ND & $\begin{array}{l}171.8 \pm 2.0^{\mathrm{d}} \\
(35.62 \pm 0.53 \%)\end{array}$ & $\begin{array}{l}105.0 \pm 3.7^{\mathrm{c}} \\
(21.76 \pm 3.31 \%)\end{array}$ & $\begin{array}{l}482.3 \pm 11.8^{\mathrm{d}} \\
(100 \%)\end{array}$ & $3.03 \pm 0.06^{\mathrm{c}}$ \\
\hline Maltose & $4.3 \pm 0.2^{\mathrm{d}}$ & $\begin{array}{c}65.5 \pm 0.5^{\mathrm{b}} \\
(18.78 \pm 0.19 \%)\end{array}$ & $\begin{array}{c}99.5 \pm 5.1^{\mathrm{a}} \\
(28.53 \pm 1.91 \%)\end{array}$ & ND & $\begin{array}{l}102.3 \pm 1.0^{\mathrm{e}} \\
(29.33 \pm 0.36 \%)\end{array}$ & $\begin{array}{c}81.5 \pm 4.1^{\mathrm{c}} \\
(23.36 \pm 2.84 \%)\end{array}$ & $\begin{array}{l}348.7 \pm 12.9^{\mathrm{e}} \\
(100 \%)\end{array}$ & $3.23 \pm 0.05^{\mathrm{b}}$ \\
\hline
\end{tabular}

The concentrations of fatty acid are expressed as mean \pm standard deviation ( $\%$ of total fatty acids) of triplicate experiments. Values in the same column that do not share the same alphabetic superscript are significantly different at $5 \%$ levels according to Duncan's multiple range tests. The basal medium was $2.0 \%$ of carbon source at initial pH 6.0 and incubated at $20{ }^{\circ} \mathrm{C}$ for 7 days. $\mathrm{ND}$ : under detection. Same abbreviations as described in Table 1. 
of PUFAs production also depended on the microbes, culture media and conditions (Shimizu et al., 1989).

Low temperature stimulated the production of highunsaturated fatty acids, such as arachidonic acid, eicosapentaenoic acid, linoleic acid and $\gamma$-linolenic acid. Total PUFAs had high yield at 12 and $15^{\circ} \mathrm{C}$, and it decreased when incubation temperature was higher than $20^{\circ} \mathrm{C}$. Each gram of carbon produced $17.4 \mathrm{mg}$ of linoleic acid, $17.0 \mathrm{mg}$ of $\gamma$-linolenic acid, $103.0 \mathrm{mg}$ of arachidonic acid and $194.2 \mathrm{mg}$ of total PUFAs at $20^{\circ} \mathrm{C}$, while it yielded $21.4 \mathrm{mg}$ of linoleic acid, $25.6 \mathrm{mg}$ of $\gamma$-linolenic acid, $2.6 \mathrm{mg}$ of $\alpha$-linolenic acid, $110.3 \mathrm{mg}$ of arachidonic acid, $4.3 \mathrm{mg}$ of eicosapentaenoic acid and $218.4 \mathrm{mg}$ of total PUFAs at $12{ }^{\circ} \mathrm{C}$. Although, low temperature incubation favored the production of PUFAs, but it slowed down the growth rate of test organism.

M. alpina had high cell growth at $15-25^{\circ} \mathrm{C}$, and it decreased at temperature higher than $28^{\circ} \mathrm{C}$ or lower than $8{ }^{\circ} \mathrm{C}$. Bajpai et al. (1991b) and Bajpai and Bajpai (1992) indicated that biomass and arachidonic acid production of M. alpina ATCC 32222 decreased when the incubation temperature was shifted from $25^{\circ} \mathrm{C}$ to $28^{\circ} \mathrm{C}$, and eicosapentaenoic acid could detect only at $10-15^{\circ} \mathrm{C}$ incubation. Ahern (1983) reported that in red alga Porphyridium cruentum, the arachidonic acid yield per cell was the highest at low temperature and low cell concentration. Low incubation temperature enhanced long chain fatty acid production, such as arachidonic acid and eicosapentaenoic acid, but it retarded the mycelial growth. $\alpha$-Linolenic acid, arachidonic acid and eicosapentaenoic acid productions were high at 12 and $15^{\circ} \mathrm{C}$. Shimizu et al. (1988) also reported that eicosapentaenoic acid produced by Mortierella at $6-16^{\circ} \mathrm{C}$, and it could not detect at $20-28{ }^{\circ} \mathrm{C}$.

\subsection{Effect of carbon source on PUFAs production}

The effect of carbon source on PUFAs production is presented in Table 3. Cell dry weight had a high value when glucose and soluble starch were used as carbon source, followed by glycerol and galactose, and maltose was the least. The final $\mathrm{pH}$ of the culture broth had a similar tendency, soluble starch and glucose gave high $\mathrm{pH}$ values (between $\mathrm{pH} 6.42$ and 7.14). Soluble starch was the best carbon source for arachidonic acid and total PUFAs production, glucose and glycerol were the next, and galactose and maltose were the poorest. Degree of unsaturation in the products was the highest when soluble starch was used as carbon source, while galactose was the lowest one. There were significant differences among the test carbon sources in PUFAs production, degree of unsaturation, cell dry weight and final $\mathrm{pH}$ value.

M. alpina can be used as arachidonic acid-producing microbes, arachidonic acid content in the total PUFAs depends on the culture conditions. Arachidonic acid was $57.3-64.8 \%$ in the total PUFAs with $2 \%$ of soluble starch as carbon source. The value increased to $78.0 \%$ with glycerol as carbon source, and it was 52.5\%, $35.6 \%$ and $29.3 \%$ with glucose, galactose and maltose as carbon source, respectively. The arachidonic acid content in the total PUFAs was of same range as that in M. alpina (78\%) (Totani and Oba, 1987) and in $M$. alpina ATCC 32222 (56\%) (Bajpai et al., 1991b), and higher than that in Mortierella sp. S-17 at C/N 10 (46\%) (Sajbidor et al., 1990), in M. alpina ATCC $16266(43 \%)$, in M. alpina ATCC 42430 (41\%) (Bajpai et al., 1991a), in M. alpina IS-4 (35\%) (Shinmen et al., 1989), in M. alpina CBS 343.66 (35\%) and the value increased to $57 \%$ after the consumption of glucose in the medium (Lindberg and Molin, 1993), in M. alpina IS-4 AKU 39998 (31\%) and in M. alpina CBS 210.32 $(6.9 \%)$ (Shinmen et al., 1989). Soluble starch and glucose as carbon source are good for cell growth, arachidonic acid and total PUFAs production. This phenomenon was consistent with Chen and Chang (1994) in M. alpina CBS 210.32, and Shinmen et al. (1989) in M. alpina IS-4.

Arachidonic acid, total PUFAs production and cell dry weight increased with increasing soluble starch concentration and they had the maximum yield at $10.0 \%$, and then decreased gradually when the concentration was higher than $12.0 \%$ (Table 4 ). At $10.0 \%$ of soluble starch, each gram of carbon could support $171.8 \mathrm{mg}$ of total PUFAs, including $5.6 \mathrm{mg}$ of linoleic acid, $5.3 \mathrm{mg}$ of $\gamma$-linolenic acid and $114.1 \mathrm{mg}$ of arachidonic acid. In the case of glucose as the sole carbon source, it had the highest cell dry weight, arachidonic acid and total PUFAs production at $6.0 \%$ of glucose, and then decreased sharply when the concentration was higher than $8 \%$. Each gram of carbon supported $167.2 \mathrm{mg}$ of total PUFAs production, including $6.6 \mathrm{mg}$ of linoleic acid, $8.3 \mathrm{mg}$ of $\gamma$-linolenic acid, and $101.1 \mathrm{mg}$ of arachidonic acid. This effect was different from M. alpina ATCC 16266 and M. alpina ATCC 32222 with high values at $10 \%$ of glucose as carbon source (Bajpai et al., 1991a,b). Koike et al. (2001) reported that fatty acids content increased with the concentration of glucose from $2.0 \%$ to $12.0 \%$ in M. alpina CBS 754.68 , while arachidonic acid content and arachidonic acid yield were reversed.

\subsection{Effect of nitrogen source and C/N ratio on PUFAs production}

The effect of nitrogen supplement on PUFA production is illustrated in Table 5. $\mathrm{KNO}_{3}$ gave the highest cell biomass and total PUFAs yield. In the mixture of inorganic and organic nitrogen source, yeast extract gave the maximal cell biomass, while the mixture of $\mathrm{KNO}_{3}$ and yeast extract $(2: 1, w / w)$ had the highest total PUFAs, 
Table 4

Effect of carbon source concentration on biomass and PUFAs production of M. alpina ATCC 32222

\begin{tabular}{|c|c|c|c|c|c|c|c|c|}
\hline Carbon source & Concentration $\left(\mathrm{g}^{-1}\right)$ & Cell dry weight $\left(\mathrm{g}^{-1}\right)$ & LA $\left(\mathrm{mg}^{-1}\right)$ & GLA $\left(\mathrm{mg} \mathrm{l}^{-1}\right)$ & $\mathrm{AA}\left(\mathrm{mg}^{-1}\right)$ & Others $\left(\mathrm{mg} \mathrm{l}^{-1}\right)$ & Total PUFAs $\left(\mathrm{mg} \mathrm{l}^{-1}\right)$ & $\Delta$ \\
\hline \multirow[t]{6}{*}{ Glucose } & 0 & $1.6 \pm 0.1^{\mathrm{e}}$ & $\begin{array}{c}1.2 \pm 0.1^{\mathrm{f}} \\
(8.15 \pm 1.30 \%)\end{array}$ & $\begin{array}{c}1.9 \pm 0.3^{\mathrm{g}} \\
(12.96 \pm 3.19 \%)\end{array}$ & $\begin{array}{c}6.9 \pm 1.2^{\mathrm{g}} \\
(45.89 \pm 12.26 \%)\end{array}$ & $\begin{array}{c}4.9 \pm 0.2^{\mathrm{d}} \\
(33.00 \pm 2.25 \%)\end{array}$ & $\begin{array}{l}15.0 \pm 1.6^{\mathrm{h}} \\
(100 \%)\end{array}$ & $2.89 \pm 0.05^{\mathrm{c}}$ \\
\hline & 20 & $7.5 \pm 2.6^{\mathrm{c}}$ & $\begin{array}{l}58.8 \pm 0.1^{\mathrm{d}} \\
(4.67 \pm 0.01 \%)\end{array}$ & $\begin{array}{l}69.2 \pm 3.5^{\mathrm{d}} \\
(5.50 \pm 0.43 \%)\end{array}$ & $\begin{array}{c}671.1 \pm 14.2^{\mathrm{c}} \\
(53.28 \pm 1.77 \%)\end{array}$ & $\begin{array}{l}460.4 \pm 10.6^{\mathrm{c}} \\
(36.55 \pm 0.06 \%)\end{array}$ & $\begin{array}{l}1259.5 \pm 4.5^{\mathrm{d}} \\
(100 \%)\end{array}$ & $3.81 \pm 0.05^{\mathrm{a}, \mathrm{b}}$ \\
\hline & 40 & $11.9 \pm 2.6^{\mathrm{b}}$ & $\begin{array}{l}142.0 \pm 7.7^{\mathrm{a}} \\
(4.17 \pm 0.35 \%)\end{array}$ & $\begin{array}{l}155.9 \pm 10.9^{\mathrm{b}} \\
(4.58 \pm 0.50 \%)\end{array}$ & $\begin{array}{r}1887.1 \pm 147.0^{\mathrm{b}} \\
(55.42 \pm 6.73 \%)\end{array}$ & $\begin{array}{l}1220.0 \pm 73.6^{\mathrm{a}} \\
(35.83 \pm 0.13 \%)\end{array}$ & $\begin{array}{l}3405.0 \pm 93.3^{\mathrm{b}} \\
(100 \%)\end{array}$ & $3.83 \pm 0.01^{\mathrm{a}}$ \\
\hline & 60 & $14.9 \pm 3.7^{\mathrm{b}}$ & $\begin{array}{l}158.4 \pm 5.0^{\mathrm{a}} \\
(3.85 \pm 0.18 \%)\end{array}$ & $\begin{array}{l}200.2 \pm 5.4^{\mathrm{a}} \\
(4.86 \pm 0.19 \%)\end{array}$ & $\begin{array}{c}2424.7 \pm 68.1^{\mathrm{a}} \\
(58.86 \pm 2.45 \%)\end{array}$ & $\begin{array}{l}1227.9 \pm 32.2^{\mathrm{a}} \\
(32.43 \pm 0.07 \%)\end{array}$ & $\begin{array}{l}4011.2 \pm 65.3^{\mathrm{a}} \\
(100 \%)\end{array}$ & $3.80 \pm 0.04^{\mathrm{a}, \mathrm{b}}$ \\
\hline & 80 & $11.8 \pm 1.5^{\mathrm{b}}$ & $\begin{array}{l}125.9 \pm 1.4^{\mathrm{a}} \\
(3.96 \pm 0.07 \%)\end{array}$ & $\begin{array}{l}110.4 \pm 3.2^{\mathrm{b}} \\
(3.47 \pm 0.15 \%)\end{array}$ & $\begin{array}{l}1858.2 \pm 2.9^{\mathrm{b}} \\
(58.49 \pm 0.14 \%)\end{array}$ & $\begin{array}{l}1082.3 \pm 11.3^{\mathrm{b}} \\
(34.06 \pm 0.16 \%)\end{array}$ & $\begin{array}{l}3176.8 \pm 21.7^{\mathrm{b}} \\
(100 \%)\end{array}$ & $3.84 \pm 0.01^{\mathrm{a}}$ \\
\hline & 100 & $5.3 \pm 1.3^{\mathrm{d}}$ & $\begin{aligned} 42.9 & \pm 2.3^{\mathrm{d}} \\
(4.91 & \pm 0.47 \%)\end{aligned}$ & $\begin{array}{c}43.6 \pm 2.2^{\mathrm{d}} \\
(4.99 \pm 0.46 \%)\end{array}$ & $\begin{aligned} 393.1 & \pm 5.7^{\mathrm{d}} \\
(44.97 & \pm 1.18 \%)\end{aligned}$ & $\begin{aligned} 401.0 & \pm 7.4^{\mathrm{c}} \\
(45.87 & \left. \pm 0.47^{\circ} \%\right)\end{aligned}$ & $\begin{array}{l}874.2 \pm 9.6^{\mathrm{e}} \\
(100 \%)\end{array}$ & $3.76 \pm 0.01^{\mathrm{b}}$ \\
\hline \multirow[t]{8}{*}{$\begin{array}{l}\text { Soluble } \\
\text { starch }\end{array}$} & 0 & $1.6 \pm 0.0^{\mathrm{e}}$ & $\begin{array}{c}1.2 \pm 0.1^{\mathrm{f}} \\
(8.15 \pm 1.30 \%)\end{array}$ & $\begin{array}{c}1.9 \pm 0.3^{\mathrm{g}} \\
(12.96 \pm 3.19 \%)\end{array}$ & $\begin{array}{c}6.9 \pm 1.2^{\mathrm{g}} \\
(45.89 \pm 12.26 \%)\end{array}$ & $\begin{array}{c}4.9 \pm 0.2^{\mathrm{d}} \\
(33.00 \pm 2.25 \%)\end{array}$ & $\begin{array}{l}15.0 \pm 1.6^{h} \\
(100 \%)\end{array}$ & $2.89 \pm 0.05^{\mathrm{c}}$ \\
\hline & 10 & $4.2 \pm 0.2^{\mathrm{d}}$ & $\begin{array}{c}17.1 \pm 0.4^{\mathrm{c}} \\
\left(12.59 \pm 0.37^{\circ} \%\right)\end{array}$ & $\begin{aligned} 8.8 & \pm 0.1^{\mathrm{f}} \\
(6.48 & \pm 0.15 \%)\end{aligned}$ & $\begin{array}{c}70.5 \pm 4.3^{\mathrm{f}} \\
(51.87 \pm 4.48 \%)\end{array}$ & $\begin{array}{c}39.5 \pm 2.3^{\mathrm{d}} \\
\left(29.06 \pm 0.85^{\circ} \%\right)\end{array}$ & $\begin{array}{l}136.0 \pm 4.0^{\mathrm{g}} \\
(100 \%)\end{array}$ & $3.85 \pm 0.02^{\mathrm{a}}$ \\
\hline & 20 & $7.2 \pm 0.4^{\mathrm{c}}$ & $\begin{array}{l}99.2 \pm 0.4^{\mathrm{e}} \\
(7.01 \pm 0.04 \%)\end{array}$ & $\begin{array}{l}95.3 \pm 6.5^{\mathrm{b}} \\
(6.73 \pm 0.64 \%)\end{array}$ & $\begin{array}{c}826.3 \pm 4.3^{\mathrm{c}} \\
(58.33 \pm 4.24 \%)\end{array}$ & $\begin{array}{l}395.8 \pm 2.7^{\mathrm{c}} \\
(27.94 \pm 0.04 \%)\end{array}$ & $\begin{array}{l}1416.7 \pm 15.2^{\mathrm{d}} \\
(100 \%)\end{array}$ & $3.87 \pm 0.01^{\mathrm{a}}$ \\
\hline & 40 & $9.6 \pm 0.9^{c}$ & $\begin{array}{l}81.0 \pm 7.1^{\mathrm{e}} \\
(4.08 \pm 0.49 \%)\end{array}$ & $\begin{aligned} 73.5 & \pm 3.1^{\mathrm{d}} \\
(3.70 & \pm 0.21 \%)\end{aligned}$ & $\begin{array}{l}1293.6 \pm 57.7^{\mathrm{b}} \\
(65.09 \pm 3.99 \%)\end{array}$ & $\begin{array}{c}539.1 \pm 10.0^{\mathrm{c}} \\
(27.13 \pm 0.66 \%)\end{array}$ & $\begin{array}{l}1978.1 \pm 57.2^{\mathrm{d}} \\
(100 \%)\end{array}$ & $3.87 \pm 0.01^{\mathrm{a}}$ \\
\hline & 60 & $14.0 \pm 2.0^{\mathrm{b}}$ & $\begin{array}{l}81.0 \pm 5.0^{\mathrm{e}} \\
(3.13 \pm 0.26 \%)\end{array}$ & $\begin{array}{l}74.0 \pm 1.0^{\mathrm{d}} \\
(2.86 \pm 0.05 \%)\end{array}$ & $\begin{array}{l}1746.3 \pm 74.1^{\mathrm{b}} \\
(67.52 \pm 3.90 \%)\end{array}$ & $\begin{array}{l}685.1 \pm 16.5^{\mathrm{c}} \\
(26.49 \pm 0.04 \%)\end{array}$ & $\begin{array}{l}2586.3 \pm 45.2^{\mathrm{c}} \\
(100 \%)\end{array}$ & $3.88 \pm 10.01^{\mathrm{a}}$ \\
\hline & 80 & $17.8 \pm 0.5^{\mathrm{b}}$ & $\begin{array}{l}91.1 \pm 2.4^{\mathrm{c}} \\
(3.07 \pm 0.11 \%)\end{array}$ & $\begin{array}{l}84.5 \pm 2.6^{\mathrm{c}} \\
(2.85 \pm 0.12 \%)\end{array}$ & $\begin{array}{c}2007.7 \pm 34.6^{\mathrm{b}} \\
(67.72 \pm 1.59 \%)\end{array}$ & $\begin{array}{c}781.5 \pm 17.5^{\mathrm{c}} \\
(26.36 \pm 0.04 \%)\end{array}$ & $\begin{array}{l}2964.7 \pm 19.1^{\mathrm{b}} \\
(100 \%)\end{array}$ & $3.94 \pm 0.05^{\mathrm{a}}$ \\
\hline & 100 & $18.4 \pm 3.0^{\mathrm{a}}$ & $\begin{array}{l}130.0 \pm 1.4^{\mathrm{a}} \\
(3.28 \pm 0.05 \%)\end{array}$ & $\begin{array}{l}122.6 \pm 4.3^{\mathrm{b}} \\
(3.09 \pm 0.15 \%)\end{array}$ & $\begin{array}{c}2636.9 \pm 369.5^{\mathrm{a}} \\
(66.42 \pm 1.28 \%)\end{array}$ & $\begin{array}{c}1080.7 \pm 16.2^{\mathrm{b}} \\
(27.221 \pm 0.31 \%)\end{array}$ & $\begin{array}{l}3970.2 \pm 53.5^{\mathrm{a}} \\
(100 \%)\end{array}$ & $3.88 \pm 0.10^{\mathrm{a}}$ \\
\hline & 120 & $17.9 \pm 3.9^{\mathrm{b}}$ & $\begin{array}{l}104.6 \pm 2.9^{\mathrm{b}} \\
(17.06 \pm 0.67 \%)\end{array}$ & $\begin{aligned} 27.4 & \pm 2.9^{\mathrm{e}} \\
(4.48 & \pm 0.67 \%)\end{aligned}$ & $\begin{array}{c}297.1 \pm 11.3^{\mathrm{e}} \\
(48.46 \pm 2.63 \%)\end{array}$ & $\begin{array}{c}184.0 \pm 11.2^{\mathrm{d}} \\
(30.01 \pm 1.00 \%)\end{array}$ & $\begin{array}{l}613.1 \pm 6.1^{\mathrm{f}} \\
(100 \%)\end{array}$ & $3.83 \pm 0.12^{\mathrm{a}}$ \\
\hline
\end{tabular}

The concentrations of fatty acid are expressed as mean \pm standard deviation ( $\%$ of total fatty acids) of triplicate experiments. Values in the same column that do not share the same alphabetic superscript are significantly different at $5 \%$ levels according to Duncan's multiple range tests. The basal medium was initial pH 6.0 and incubated at $20{ }^{\circ} \mathrm{C}$ for 7 days. ND: under detection. Same abbreviations as described in Table 1. 
Table 5

Effect of nitrogen source on $\mathrm{pH}$, biomass and PUFAs production of M. alpina ATCC 32222

\begin{tabular}{|c|c|c|c|c|c|c|c|c|c|}
\hline Nitrogen source & $\mathrm{C} / \mathrm{N}$ ratio & Final $\mathrm{pH}$ & Cell dry weight $\left(\mathrm{g}^{-1}\right)$ & LA $\left(\mathrm{mg} \mathrm{l}^{-1}\right)$ & GLA $\left(\mathrm{mg} \mathrm{l}^{-1}\right)$ & $\mathrm{AA}\left(\mathrm{mg} \mathrm{1^{-1 } )}\right.$ & Others $\left(\mathrm{mg} \mathrm{l}^{-1}\right)$ & Total PUFAs $\left(\mathrm{mg} \mathrm{l}^{-1}\right)$ & $\Delta$ \\
\hline $\mathrm{KNO}_{3}$ & 6.2 & $7.5 \pm 0.3^{b}$ & $6.5 \pm 0.5^{\mathrm{b}}$ & $\begin{array}{l}47.0 \pm 0.3^{\mathrm{b}} \\
(4.51 \pm 0.04 \%)\end{array}$ & $\begin{array}{l}53.9 \pm 1.0^{\mathrm{b}} \\
(5.18 \pm 0.14 \%)\end{array}$ & $\begin{array}{c}622.4 \pm 17.1^{\mathrm{b}} \\
(59.73 \pm 2.36 \%)\end{array}$ & $\begin{array}{c}318.7 \pm 8.4^{\mathrm{b}, \mathrm{c}} \\
(30.58 \pm 0.61 \%)\end{array}$ & $\begin{array}{l}1042.1 \pm 33.4^{\mathrm{a}} \\
(100 \%)\end{array}$ & $3.82 \pm 0.01^{\mathrm{b}}$ \\
\hline $\mathrm{NaNO}_{3}$ & 5.4 & $6.9 \pm 0.2^{\mathrm{b}}$ & $6.9 \pm 0.3^{\mathrm{b}}$ & $\begin{array}{l}29.8 \pm 0.7^{\mathrm{c}} \\
(3.38 \pm 0.11 \%)\end{array}$ & $\begin{array}{c}37.2 \pm 0.4^{\mathrm{c}} \\
(4.22 \pm 0.06 \%)\end{array}$ & $\begin{array}{c}569.2 \pm 18.9^{c} \\
(64.57 \pm 2.96 \%)\end{array}$ & $\begin{array}{l}245.3 \pm 7.6^{\mathrm{c}} \\
(27.83 \pm 2.29 \%)\end{array}$ & $\begin{array}{l}881.5 \pm 9.2^{\mathrm{b}} \\
(100 \%)\end{array}$ & $3.73 \pm 0.01^{\mathrm{b}}$ \\
\hline $\mathrm{NH}_{4} \mathrm{NO}_{3}$ & 2.5 & $3.8 \pm 0.1^{\mathrm{e}}$ & $5.7 \pm 0.1^{\mathrm{b}}$ & $\begin{aligned} 43.9 & \pm 2.6^{\mathrm{b}} \\
(5.59 & \pm 0.42 \%)\end{aligned}$ & $\begin{aligned} 46.7 & \pm 1.6^{\mathrm{b}} \\
(5.94 & \pm 0.25 \%)\end{aligned}$ & $\begin{aligned} 528.1 & \pm 20.5^{\mathrm{c}} \\
(67.21 & \pm 3.31 \%)\end{aligned}$ & $\begin{array}{l}167.1 \pm 7.3^{\mathrm{d}} \\
(21.26 \pm 0.23 \%)\end{array}$ & $\begin{array}{l}785.8 \pm 14.6^{\mathrm{b}} \\
(100 \%)\end{array}$ & $3.59 \pm 0.01^{\mathrm{c}}$ \\
\hline$\left(\mathrm{NH}_{4}\right)_{2} \mathrm{SO}_{4}$ & 4.2 & $4.7 \pm 0.1^{\mathrm{d}}$ & $2.6 \pm 0.1^{\mathrm{c}}$ & $\begin{array}{c}26.9 \pm 2.0^{\mathrm{c}} \\
(29.42 \pm 2.23 \%)\end{array}$ & $\begin{array}{c}15.7 \pm 0.8^{\mathrm{d}} \\
(17.20 \pm 0.89 \%)\end{array}$ & $\begin{array}{c}48.8 \pm 5.5^{\mathrm{e}} \\
(53.38 \pm 6.06 \%)\end{array}$ & $\begin{array}{c}59.3 \pm 4.1^{\mathrm{e}} \\
(39.32 \pm 5.31 \%)\end{array}$ & $\begin{array}{l}150.7 \pm 4.1^{\mathrm{c}} \\
(100 \%)\end{array}$ & $3.20 \pm 0.01^{\mathrm{e}}$ \\
\hline Urea & 1.9 & $8.2 \pm 0.1^{\mathrm{a}}$ & $0.6 \pm 0.0^{\mathrm{d}}$ & $\begin{array}{c}3.9 \pm 0.6^{\mathrm{d}} \\
(13.79 \pm 3.53 \%)\end{array}$ & $\begin{array}{c}2.4 \pm 0.2^{\mathrm{e}} \\
(8.42 \pm 1.31 \%)\end{array}$ & $\begin{array}{c}11.4 \pm 1.5^{\mathrm{e}} \\
(40.70 \pm 8.77 \%)\end{array}$ & $\begin{array}{c}10.4 \pm 1.2^{\mathrm{e}} \\
(37.08 \pm 1.21 \%)\end{array}$ & $\begin{array}{l}27.9 \pm 0.9^{\mathrm{d}} \\
(100 \%)\end{array}$ & $3.47 \pm 0.01^{\mathrm{c}}$ \\
\hline Yeast extract & 9.0 & $8.5 \pm 0.3^{\mathrm{a}}$ & $9.9 \pm 0.1^{\mathrm{a}}$ & $\begin{array}{l}54.5 \pm 1.5^{\mathrm{b}} \\
(3.91 \pm 0.25 \%)\end{array}$ & $\begin{array}{c}81.5 \pm 8.1^{\mathrm{a}} \\
(5.85 \pm 1.34 \%)\end{array}$ & $\begin{array}{c}468.7 \pm 8.9^{\mathrm{d}} \\
(33.62 \pm 1.48 \%)\end{array}$ & $\begin{array}{c}789.6 \pm 11.3^{\mathrm{a}} \\
(56.63 \pm 8.05 \%)\end{array}$ & $\begin{array}{l}1394.3 \pm 18.5^{\mathrm{a}} \\
(100 \%)\end{array}$ & $3.72 \pm 0.02^{\mathrm{b}}$ \\
\hline $\mathrm{KNO}_{3}$ : Yeast extract $(1: 3, \mathrm{w} / \mathrm{w})$ & 7.6 & $7.8 \pm 0.4^{\mathrm{b}}$ & $9.3 \pm 0.3^{\mathrm{a}}$ & $\begin{array}{l}56.9 \pm 3.1^{\mathrm{b}} \\
(5.83 \pm 0.60 \%)\end{array}$ & $\begin{array}{l}50.3 \pm 4.7^{\mathrm{b}} \\
(5.16 \pm 0.82 \%)\end{array}$ & $\begin{array}{c}473.0 \pm 20.2^{\mathrm{d}} \\
(48.49 \pm 3.48 \%)\end{array}$ & $\begin{array}{c}395.2 \pm 11.8^{\mathrm{b}} \\
(40.52 \pm 0.75 \%)\end{array}$ & $\begin{array}{l}975.4 \pm 19.2^{\mathrm{a}} \\
(100 \%)\end{array}$ & $3.77 \pm 0.01^{\mathrm{b}}$ \\
\hline $\mathrm{KNO}_{3}$ : Yeast extract $(1: 2, \mathrm{w} / \mathrm{w})$ & 7.1 & $7.6 \pm 0.2^{\mathrm{b}}$ & $7.2 \pm 0.1^{\mathrm{b}}$ & $\begin{array}{c}31.4 \pm 1.5^{\mathrm{c}} \\
(4.63 \pm 0.30 \%)\end{array}$ & $\begin{array}{l}32.0 \pm 0.4^{\mathrm{c}} \\
(4.73 \pm 0.09 \%)\end{array}$ & $\begin{array}{c}435.2 \pm 31.3^{\mathrm{d}} \\
(64.22 \pm 6.28 \%)\end{array}$ & $\begin{array}{c}246.9 \pm 12.2^{\mathrm{c}} \\
(36.43 \pm 3.43 \%)\end{array}$ & $\begin{array}{l}677.7 \pm 20.8^{\mathrm{b}} \\
(100 \%)\end{array}$ & $3.78 \pm 0.02^{\mathrm{b}}$ \\
\hline $\mathrm{KNO}_{3}:$ Yeast extract $(1: 1, \mathrm{w} / \mathrm{w})$ & 6.2 & $7.6 \pm 0.1^{b}$ & $8.5 \pm 0.1^{b}$ & $\begin{array}{l}27.2 \pm 2.7^{\mathrm{c}} \\
(2.88 \pm 0.46 \%)\end{array}$ & $\begin{array}{l}25.0 \pm 1.3^{\mathrm{c}} \\
\left(2.65 \pm 0.22^{\circ} \%\right)\end{array}$ & $\begin{array}{l}538.9 \pm 4.1^{\mathrm{c}} \\
\left(57.13 \pm 0.69^{\circ} \%\right)\end{array}$ & $\begin{array}{c}352.2 \pm 7.4^{\mathrm{b}, \mathrm{c}} \\
(37.34 \pm 0.83 \%)\end{array}$ & $\begin{array}{l}943.3 \pm 8.1^{\mathrm{a}} \\
(100 \%)\end{array}$ & $3.79 \pm 0.06^{\mathrm{b}}$ \\
\hline $\mathrm{KNO}_{3}$ : Yeast extract $(2: 1, \mathrm{w} / \mathrm{w})$ & 5.2 & $5.9 \pm 0.0^{\mathrm{c}}$ & $7.2 \pm 0.1^{\mathrm{b}}$ & $\begin{array}{l}99.2 \pm 0.4^{\mathrm{a}} \\
(6.89 \pm 0.04 \%)\end{array}$ & $\begin{array}{l}96.3 \pm 6.5^{\mathrm{a}} \\
(6.68 \pm 0.64 \%)\end{array}$ & $\begin{array}{l}826.3 \pm 4.2^{\mathrm{a}} \\
(57.37 \pm 0.41 \%)\end{array}$ & $\begin{array}{l}418.6 \pm 7.6^{\mathrm{b}} \\
(29.06 \pm 0.06 \%)\end{array}$ & $\begin{array}{l}1440.5 \pm 11.6^{\mathrm{a}} \\
(100 \%)\end{array}$ & $3.87 \pm 0.01^{\mathrm{a}}$ \\
\hline $\mathrm{KNO}_{3}$ : Yeast extract $(3: 1, \mathrm{w} / \mathrm{w})$ & 5.1 & $5.2 \pm 0.2^{\mathrm{c}}$ & $6.9 \pm 0.4^{\mathrm{b}}$ & $\begin{array}{c}52.3 \pm 1.9^{\mathrm{b}} \\
(4.13 \pm 0.23 \%)\end{array}$ & $\begin{array}{c}56.4 \pm 2.2^{\mathrm{b}} \\
(4.45 \pm 0.26 \%)\end{array}$ & $\begin{array}{c}726.4 \pm 13.5^{\mathrm{b}} \\
(57.40 \pm 1.62 \%)\end{array}$ & $\begin{array}{c}430.6 \pm 6.5^{\mathrm{b}} \\
(34.02 \pm 0.07 \%)\end{array}$ & $\begin{array}{l}1265.6 \pm 13.8^{\mathrm{a}} \\
(100 \%)\end{array}$ & $3.81 \pm 0.01^{\mathrm{b}}$ \\
\hline
\end{tabular}

The concentrations of fatty acid are expressed as mean \pm standard deviation ( $\%$ of total fatty acids) of triplicate experiments. Values in the same column that do not share the same alphabetic superscript are significantly different at $5 \%$ levels according to Duncan's multiple range tests. The basal medium was $2.0 \%$ of soluble starch as carbon source at initial pH 6.0 and incubated at $20{ }^{\circ} \mathrm{C}$ for 7 days. Same abbreviations as described in Table 1. 
linoleic acid, $\gamma$-linolenic acid and arachidonic acid production.

Nitrate as nitrogen source showed a high cell growth, total PUFAs, and arachidonic acid production, whereas ammonium and urea had low value. This might be due to the neutral $\mathrm{pH}$ in the nitrate salt amendment, while an acidic $\mathrm{pH}$ was observed in ammonium salt supplementation. The mixture of $\mathrm{KNO}_{3}$ and yeast extract as nitrogen source enhanced the cell growth, total PUFAs and arachidonic acid production. Total PUFAs and arachidonic acid production had the maximal value at the ratio of $\mathrm{KNO}_{3}$ to yeast extract 2:1. Yeast extract as the sole nitrogen source stimulated the cell growth, but not for arachidonic acid and total PUFAs production. Chang and Chen (1994) indicated that $\mathrm{KNO}_{3}$ was the best nitrogen source for arachidonic acid and total PUFAs production, while Bajpai and Bajpai (1992) reported that $1 \%$ of yeast extract was the optimum concentration for arachidonic acid production and high amount of yeast extract supplementation promoted the cell growth. Park et al. (1999) also indicated that nitrogen source affected the mycelial morphology and arachidonic acid production of $M$. alpina CBS 754.68. Feather-like morphology with soybean meal as nitrogen source suitable for arachidonic acid production.

The $\mathrm{C} / \mathrm{N}$ ratio was 5.2 with $2.0 \%$ of soluble starch as carbon source and $1.5 \%$ of the mixture of $\mathrm{KNO}_{3}$ and yeast extract $(2: 1, w / w)$ as nitrogen source. The effect of $\mathrm{C} / \mathrm{N}$ ratio on PUFA production is shown in Table 6. A $\mathrm{C} / \mathrm{N}$ ratio of 9.0 gave a high cell yield, whereas a $\mathrm{C} / \mathrm{N}$ ratio of 5.2 gave the maximal arachidonic acid and total PUFAs production. Arachidonic acid content decreased sharply when the $\mathrm{C} / \mathrm{N}$ ratio was lower than 2.5 or higher than 48.3. There were significant differences among $\mathrm{C} / \mathrm{N}$ ratios, final $\mathrm{pH}$, cell dry weight and PUFA production.

From the elemental analysis, $M$. alipina ATCC 32222 contained $30.79 \%$ of carbon and $6.30 \%$ of nitrogen, and $\mathrm{C} / \mathrm{N}$ ratio was 4.9 . The optimal $\mathrm{C} / \mathrm{N}$ ratio for total PUFAs and arachidonic acid production was 5.2, and the production decreased gradually with increasing of $\mathrm{C} / \mathrm{N}$ ratio. Cell growth, total PUFAs and arachidonic acid production reduced when the $\mathrm{C} / \mathrm{N}$ ratio was 2.5 or 48.3 , but the percentage of arachidonic acid in total PUFAs increased from $\mathrm{C} / \mathrm{N}$ ratio 2.5 to 9.0 , and then decreased gradually as $\mathrm{C} / \mathrm{N}$ ratio higher than 12.8. However, Sajbidor et al. (1990) reported that Mortierella sp. S-17 had high arachidonic acid concentration in the cell cultivated at $\mathrm{C} / \mathrm{N}$ ratio 10 , and had high arachidonic acid production at $\mathrm{C} / \mathrm{N}$ ratio 20 . Koike et al. (2001) also reported that the optimal $\mathrm{C} / \mathrm{N}$ ratio of the medium was around $15-20$ for arachidonic acid production in a culture of $M$. alpina CBS 754.68. When the $\mathrm{C} / \mathrm{N}$ ratio was higher than 20 the mycelia weight and arachidonic acid decreased due to nitrogen limitation.

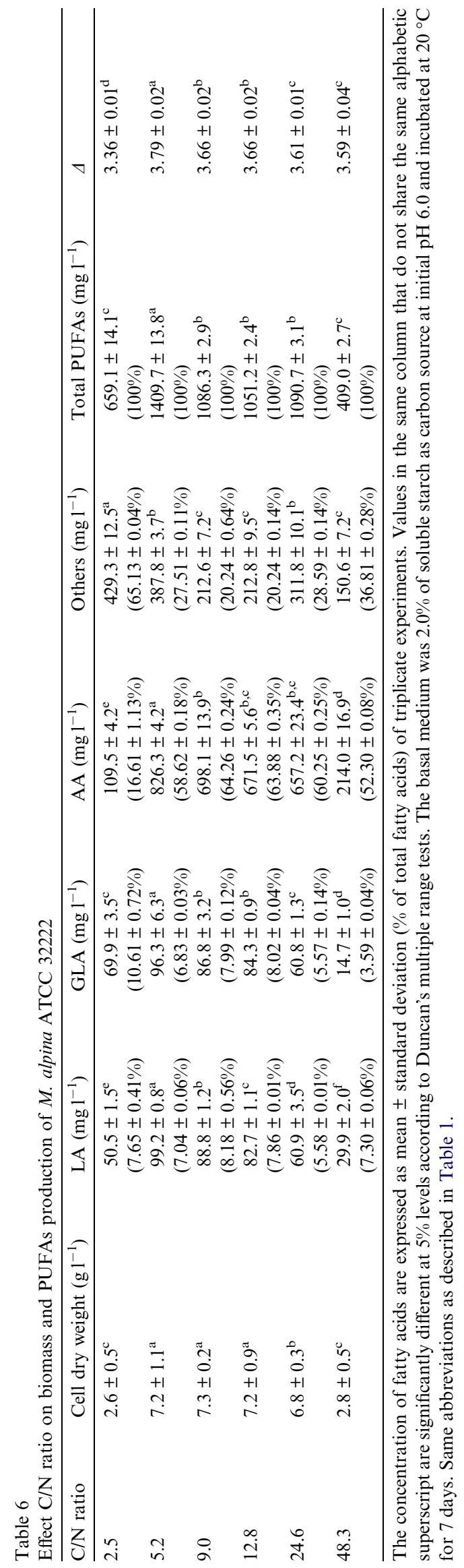




\subsection{Effect of oil supplement on PUFAs production}

The effect of oil supplement on the yield of PUFA is illustrated in Table 7 . Supplementation with $1 \%$ of oil increased the biomass production, and linseed oil gave the highest biomass, and then followed by sunflower oil and soybean oil. In case of PUFAs production, supplementation of linseed oil gave a high arachidonic acid production, followed by soybean oil and sunflower oil. Eicosapentaenoic acid production was high with a linseed oil supplement, followed by lard oil and soybean oil. Docosahexaenoic acid production had high value with the supplement of sunflower oil, and then followed by linseed oil. In the ratios of fatty acid to total PUFAs content, docosahexaenoic acid ratio was high with a peanut oil supplement, eicosapentaenoic acid ratio was high with a linseed oil supplement, and arachidonic acid ratio was high with corn oil and soybean oil amendment. Shinmen et al. (1989) also indicated that olive oil and soybean oil addition increased the accumulation of arachidonic acid.

The effect of soybean oil concentration on PUFAs production is presented in Table 8. Biomass increased with the concentration of soybean oil and it had a plateau at $1.0 \%$. The yields of total PUFAs, linoleic acid, arachidonic acid, eicosapentaenoic acid and docosahexaenoic acid also increased with the increasing concentration of soybean oil supplement, and they had the maximal values at $1.0 \%$ of soybean oil. However, soybean oil supplement inhibited the production of $\gamma$ linolenic acid. The percentage of arachidonic acid and the degree of unsaturation decreased with the concentration of soybean oil supplement, while the percentages of linoleic acid and other than the stated PUFAs were reversed. Docosahexaenoic acid and eicosapentaenoic acid content had high values at $1.0 \%$ of soybean oil supplement.

Linoleic acid is the major fatty acid in soybean oil, corn oil, peanut oil and sunflower oil (contained 56$85 \%$ ), and $\alpha$-linolenic acid was the major fatty acid in linseed oil (58\%). Saturated fatty acid (23\%) and linoleic acid $(15 \%)$ were the major fatty acids in lard oil. Supplementation of oil stimulated the cell growth, eicosapentaenoic acid, docosahexaenoic acid, arachidonic acid and total PUFAs production in M. alpina. Linseed oil was the most effective, followed by soybean oil and sunflower oil. Arachidonic acid production was more obvious in linseed oil supplementation. Jareokitmongkol et al. (1993) suggested that 3\% of linseed oil amendment produced $1 \mathrm{~g}^{-1}$ of eicosapentaenoic acid in M. alpina ( $20 \%$ of total fatty acid). In case of soybean oil, it contained linoleic acid $(56 \%)$, oleic acid $(16 \%)$, palmitic acid $(15 \%)$, and $\alpha$-linolenic acid $(7 \%)$. These fatty acids were the precursors of long chain fatty acids. However, arachidonic acid production decreased with the supplementation of soybean oil, while eicosapentaenoic acid and

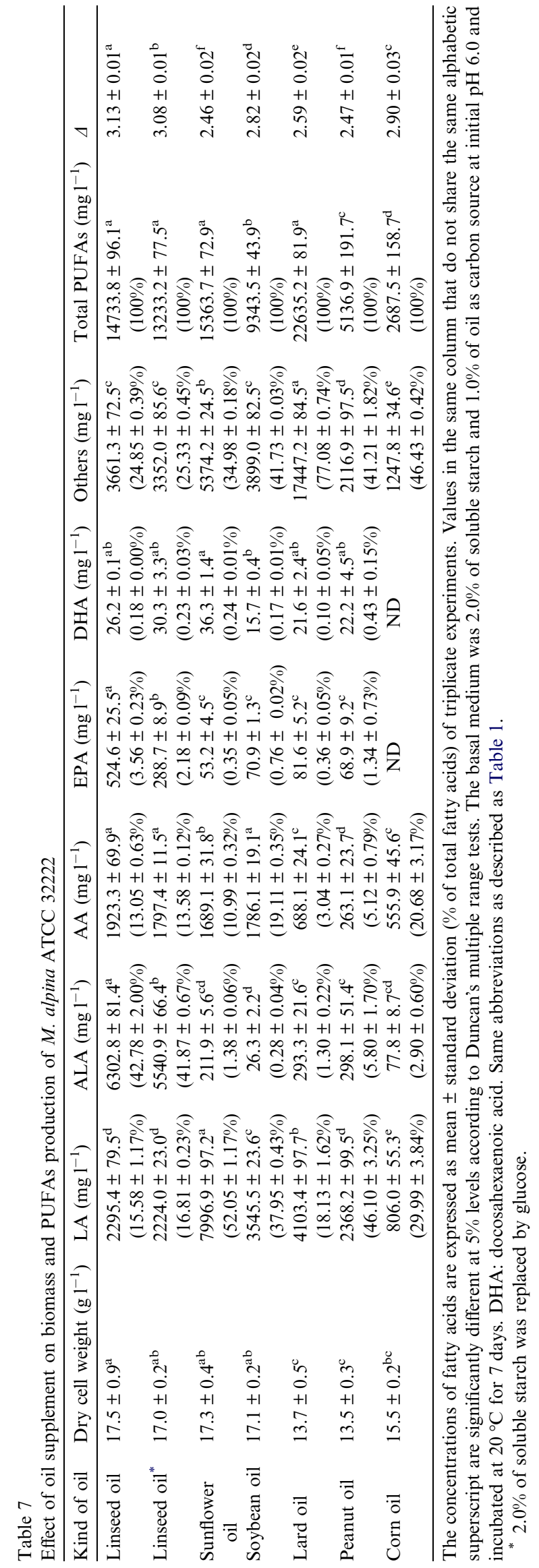


Table 8

Effect of soybean oil concentration on PUFAs production of M. alpina ATCC 32222

\begin{tabular}{|c|c|c|c|c|c|c|c|c|c|c|}
\hline Soybean oil (\%) & $\begin{array}{l}\text { Cell dry } \\
\text { weight }\left(\mathrm{g}^{-1}\right)\end{array}$ & $\begin{array}{l}\mathrm{LA} \\
\left(\mathrm{mg}^{-1}\right)\end{array}$ & $\begin{array}{l}\text { GLA } \\
\left(\mathrm{mg} \mathrm{l}^{-1}\right)\end{array}$ & $\begin{array}{l}\text { ALA } \\
\left(\mathrm{mg} \mathrm{l}^{-1}\right)\end{array}$ & $\begin{array}{l}\text { AA } \\
\left(\mathrm{mg}^{-1}\right)\end{array}$ & $\begin{array}{l}\text { EPA } \\
\left(\mathrm{mg} \mathrm{l}^{-1}\right)\end{array}$ & $\begin{array}{l}\text { DHA } \\
\left(\mathrm{mg}^{-1}\right)\end{array}$ & $\begin{array}{l}\text { Others } \\
\left(\mathrm{mg}^{-1}\right)\end{array}$ & $\begin{array}{l}\text { Total PUFAs } \\
\left(\mathrm{mg} \mathrm{l}^{-1}\right)\end{array}$ & $\Delta$ \\
\hline 0.0 & $7.2 \pm 0.4^{\mathrm{c}}$ & $\begin{array}{c}99.2 \pm 0.4^{\mathrm{e}} \\
(6.85 \pm 0.10 \%)\end{array}$ & $\begin{array}{l}96.3 \pm 6.5 \\
(6.64 \pm 0.03 \%)\end{array}$ & ND & $\begin{array}{c}826.3 \pm 4.3^{\mathrm{d}} \\
(57.02 \pm 0.08 \%)\end{array}$ & ND & ND & $\begin{array}{c}421.1 \pm 2.2^{\mathrm{d}} \\
(29.06 \pm 0.06 \%)\end{array}$ & $\begin{array}{l}1449.2 \pm 6.4^{\mathrm{e}} \\
(100 \%)\end{array}$ & $3.87 \pm 0.01^{\mathrm{a}}$ \\
\hline 0.2 & $10.3 \pm 0.8^{\mathrm{d}}$ & $\begin{array}{c}402.5 \pm 36.0^{\mathrm{d}} \\
(21.99 \pm 0.07 \%)\end{array}$ & ND & ND & $\begin{array}{c}798.1 \pm 74.8^{\mathrm{d}} \\
(43.60 \pm 0.03 \%)\end{array}$ & $\begin{array}{l}20.6 \pm 1.6^{\mathrm{c}} \\
(1.13 \pm 0.02 \%)\end{array}$ & ND & $\begin{array}{c}609.4 \pm 52.1^{\mathrm{c}} \\
(33.29 \pm 0.06 \%)\end{array}$ & $\begin{array}{l}1830.7 \pm 92.5^{\mathrm{d}} \\
(100 \%)\end{array}$ & $3.44 \pm 0.01^{\mathrm{b}}$ \\
\hline 0.5 & $12.2 \pm 1.2^{\mathrm{c}}$ & $\begin{array}{c}864.5 \pm 83.8^{\mathrm{c}} \\
(29.81 \pm 0.41 \%)\end{array}$ & ND & ND & $\begin{array}{l}1027.6 \pm 65.6^{c} \\
(35.43 \pm 0.68 \%)\end{array}$ & $\begin{array}{l}37.7 \pm 3.0^{\mathrm{b}} \\
(1.30 \pm 0.01 \%)\end{array}$ & ND & $\begin{array}{c}970.4 \pm 44.3^{\mathrm{b}} \\
(33.46 \pm 0.27 \%)\end{array}$ & $\begin{array}{l}2900.1 \pm 86.4^{\mathrm{c}} \\
(100 \%)\end{array}$ & $3.23 \pm 0.02^{\mathrm{c}}$ \\
\hline 0.8 & $15.1 \pm 0.3^{\mathrm{b}}$ & $\begin{array}{c}874.8 \pm 85.3^{\mathrm{c}} \\
\left(28.58 \pm 0.33^{\circ} \%\right)\end{array}$ & ND & ND & $\begin{array}{l}1185.3 \pm 75.6^{\mathrm{c}} \\
(38.77 \pm 0.06 \%)\end{array}$ & $\begin{array}{c}43.4 \pm 3.8^{\mathrm{b}} \\
(1.42 \pm 0.13 \%)\end{array}$ & $\begin{array}{c}1.1 \pm 0.0^{\mathrm{c}} \\
(0.03 \pm 0.01 \%)\end{array}$ & $\begin{array}{c}953.5 \pm 55.1^{\mathrm{b}} \\
\left(31.19 \pm 0.62^{\circ} \%\right)\end{array}$ & $\begin{array}{l}3057.1 \pm 78.1^{\mathrm{c}} \\
(100 \%)\end{array}$ & $3.07 \pm 0.04^{\mathrm{d}}$ \\
\hline 1.0 & $17.1 \pm 0.6^{\mathrm{a}}$ & $\begin{array}{l}3545.5 \pm 85.5^{\mathrm{a}} \\
\left(37.96 \pm 0.52^{\circ} \%\right)\end{array}$ & ND & $\begin{array}{l}26.3 \pm 2.2^{\mathrm{b}} \\
(0.28 \pm 0.01 \%)\end{array}$ & $\begin{array}{l}1786.1 \pm 11.5^{\mathrm{a}} \\
(19.12 \pm 0.51 \%)\end{array}$ & $\begin{array}{c}70.9 \pm 13.1^{\mathrm{a}} \\
\left(0.76 \pm 0.09^{\circ} \%\right)\end{array}$ & $\begin{array}{l}15.7 \pm 0.4^{\mathrm{a}} \\
(0.17 \pm 0.01 \%)\end{array}$ & $\begin{array}{l}3896.1 \pm 22.4^{\mathrm{a}} \\
(41.71 \pm 0.03 \%)\end{array}$ & $\begin{array}{l}9340.9 \pm 99.4^{\mathrm{a}} \\
(100 \%)\end{array}$ & $2.82 \pm 0.02^{\mathrm{e}}$ \\
\hline 1.5 & $18.0 \pm 2.1^{\mathrm{a}}$ & $\begin{array}{l}2191.9 \pm 99.9^{\mathrm{b}} \\
(32.11 \pm 0.46 \%)\end{array}$ & ND & $\begin{array}{l}35.2 \pm 1.0^{\mathrm{a}} \\
(0.52 \pm 0.05 \%)\end{array}$ & $\begin{array}{l}1511.4 \pm 59.1^{\mathrm{b}} \\
(22.14 \pm 0.15 \%)\end{array}$ & $\begin{array}{l}60.1 \pm 0.7^{\mathrm{a}} \\
(0.88 \pm 0.07 \%)\end{array}$ & $\begin{array}{l}10.3 \pm 1.9^{\mathrm{b}} \\
(0.15 \pm 0.01 \%)\end{array}$ & $\begin{array}{l}3017.1 \pm 67.5^{\mathrm{a}} \\
(44.20 \pm 0.19 \%)\end{array}$ & $\begin{array}{l}6826.0 \pm 90.2^{b} \\
(100 \%)\end{array}$ & $2.77 \pm 0.02^{\mathrm{f}}$ \\
\hline
\end{tabular}

The concentrations of fatty acids are expressed as mean \pm standard deviation ( $\%$ of total fatty acids) of triplicate experiments. Values in the same column that do not share the same alphabetic superscript are significantly different at $5 \%$ levels according to Duncan's multiple range tests. The basal medium was $2.0 \%$ of soluble starch as carbon source at initial pH 6.0 and incubated at $20{ }^{\circ} \mathrm{C}$ for 7 days. Same abbreviations as described as Table 1.

Table 9

Effect of carbon source with $1.0 \%$ soybean oil supplement on the PUFAs production of M. alpina ATCC 32222

\begin{tabular}{|c|c|c|c|c|c|c|c|c|c|}
\hline Carbon source $\left(\mathrm{g} \mathrm{l}^{-1}\right)$ & & Cell dry weight $\left(\mathrm{g}^{-1}\right)$ & $\mathrm{LA}\left(\mathrm{mg}^{-1}\right)$ & $\operatorname{ALA}\left(\mathrm{mg} \mathrm{l}^{-1}\right)$ & $\mathrm{AA}\left(\mathrm{mg}^{-1}\right)$ & EPA $\left(\mathrm{mg}^{-1}\right)$ & Others $\left(\mathrm{mg} \mathrm{l}^{-1}\right)$ & Total PUFAs $\left(\mathrm{mg}^{-1}\right)$ & $\Delta$ \\
\hline \multirow[t]{4}{*}{ Soluble starch } & 20 & $10.2 \pm 0.8^{\mathrm{d}}$ & $\begin{array}{c}402.5 \pm 57.5^{\mathrm{d}} \\
(21.72 \pm 1.08 \%)\end{array}$ & $\begin{array}{l}19.9 \pm 1.2^{\mathrm{e}} \\
(1.07 \pm 0.01 \%)\end{array}$ & $\begin{array}{c}798.1 \pm 15.4^{\mathrm{f}} \\
(43.07 \pm 0.36 \%)\end{array}$ & $\begin{array}{l}20.6 \pm 1.3^{\mathrm{d}} \\
\left(1.11 \pm 0.03^{\circ} \%\right)\end{array}$ & $\begin{array}{c}611.8 \pm 8.6^{\mathrm{e}} \\
(33.02 \pm 0.87 \%)\end{array}$ & $\begin{array}{l}1852.9 \pm 102.0^{\mathrm{f}} \\
(100 \%)\end{array}$ & $3.44 \pm 0.01^{\mathrm{d}}$ \\
\hline & 40 & $16.4 \pm 0.2^{\mathrm{c}}$ & $\begin{array}{l}1676.0 \pm 92.4^{\mathrm{b}, \mathrm{c}} \\
(35.54 \pm 0.21 \%)\end{array}$ & $\begin{array}{l}24.7 \pm 1.4^{\mathrm{d}} \\
(0.52 \pm 0.02 \%)\end{array}$ & $\begin{aligned} 1812.71 & \pm 66.7^{\mathrm{d}} \\
(38.44 & \pm 1.21 \%)\end{aligned}$ & $\begin{array}{l}21.0 \pm 1.0^{\mathrm{d}} \\
(0.44 \pm 0.07 \%)\end{array}$ & $\begin{array}{l}1181.4 \pm 42.2^{\mathrm{c}} \\
\left(25.05 \pm 0.69^{\circ} \%\right)\end{array}$ & $\begin{array}{l}4716.1 \pm 169.8^{d} \\
(100 \%)\end{array}$ & $3.56 \pm 0.02^{\mathrm{b}}$ \\
\hline & 60 & $23.0 \pm 0.4^{\mathrm{b}}$ & $\begin{array}{l}1644.2 \pm 88.0^{\mathrm{b}, \mathrm{c}} \\
(24.11 \pm 0.61 \%)\end{array}$ & $\begin{array}{l}31.0 \pm 2.2^{\mathrm{a}} \\
(0.45 \pm 0.02 \%)\end{array}$ & $\begin{array}{l}3750.9 \pm 56.2^{\mathrm{a}} \\
(55.01 \pm 1.27 \%)\end{array}$ & $\begin{array}{l}25.8 \pm 0.7^{\mathrm{c}} \\
(0.38 \pm 0.23 \%)\end{array}$ & $\begin{array}{l}1367.2 \pm 35.4^{\mathrm{b}} \\
(20.05 \pm 0.13 \%)\end{array}$ & $\begin{array}{l}6819.1 \pm 156.2^{\mathrm{a}} \\
\left(100^{\circ}\right)\end{array}$ & $3.63 \pm 0.01^{\mathrm{a}}$ \\
\hline & 80 & $23.2 \pm 1.0^{\mathrm{b}}$ & $\begin{array}{l}1786.7 \pm 97.3^{\mathrm{b}} \\
\left(27.69 \pm 0.39^{\circ} \%\right)\end{array}$ & $\begin{array}{l}30.1 \pm 1.0^{\mathrm{a}} \\
(0.47 \pm 0.02 \%)\end{array}$ & $\begin{array}{l}3686.5 \pm 21.2^{\mathrm{a}} \\
\left(57.14 \pm 0.47^{\circ} \%\right)\end{array}$ & $\begin{array}{l}36.8 \pm 1.3^{\mathrm{a}} \\
(0.57 \pm 0.41 \%)\end{array}$ & $\begin{array}{c}911.6 \pm 30.0^{\mathrm{d}} \\
(14.13 \pm 0.52 \%)\end{array}$ & $\begin{array}{l}6451.7 \pm 40.7^{\mathrm{b}} \\
(100 \%)\end{array}$ & $3.66 \pm 0.01^{\mathrm{a}}$ \\
\hline \multirow[t]{4}{*}{ Glucose } & 20 & $10.7 \pm 0.3^{\mathrm{d}}$ & $\begin{array}{c}471.7 \pm 45.3^{\mathrm{d}} \\
(19.14 \pm 1.04 \%)\end{array}$ & $\begin{array}{l}15.4 \pm 2.0^{\mathrm{f}} \\
(0.63 \pm 0.06 \%)\end{array}$ & $\begin{array}{l}1379.1 \pm 79.7^{\mathrm{e}} \\
(55.97 \pm 0.83 \%)\end{array}$ & $\begin{array}{l}19.7 \pm 0.8^{\mathrm{d}} \\
(0.80 \pm 0.33 \%)\end{array}$ & $\begin{array}{l}578.1 \pm 7.2^{\mathrm{e}} \\
(23.46 \pm 1.06 \%)\end{array}$ & $\begin{array}{l}2464.1 \pm 57.2^{\mathrm{e}} \\
(100 \%)\end{array}$ & $3.47 \pm 0.02^{\mathrm{c}, \mathrm{d}}$ \\
\hline & 40 & $17.3 \pm 0.8^{\mathrm{c}}$ & $\begin{array}{l}1571.1 \pm 35.0^{\mathrm{c}} \\
(25.90 \pm 1.46 \%)\end{array}$ & $\begin{array}{l}26.0 \pm 1.4^{\mathrm{c}} \\
\left(0.43 \pm 0.02^{\%} \%\right)\end{array}$ & $\begin{array}{l}2713.8 \pm 99.4^{\mathrm{c}} \\
\left(44.74 \pm 0.37^{\circ} \%\right)\end{array}$ & $\begin{array}{l}21.0 \pm 1.2^{\mathrm{d}} \\
(0.35 \pm 0.12 \%)\end{array}$ & $\begin{array}{l}1733.5 \pm 62.4^{\mathrm{a}} \\
\left(28.58 \pm 1.52^{\%} \%\right)\end{array}$ & $\begin{array}{l}6065.3 \pm 114.1^{\mathrm{c}} \\
(100 \%)\end{array}$ & $3.51 \pm 0.02^{\mathrm{c}}$ \\
\hline & 60 & $23.6 \pm 0.4^{\mathrm{a}, \mathrm{b}}$ & $\begin{array}{l}1989.2 \pm 93.2^{\mathrm{a}} \\
(29.81 \pm 2.44 \%)\end{array}$ & $\begin{array}{l}28.7 \pm 0.9^{\mathrm{b}} \\
(0.43 \pm 0.01 \%)\end{array}$ & $\begin{array}{l}3274.4 \pm 176.4^{b} \\
(49.07 \pm 2.06 \%)\end{array}$ & $\begin{array}{l}23.8 \pm 0.3^{\mathrm{c}} \\
\left(0.36 \pm 0.42^{\%} \%\right)\end{array}$ & $\begin{array}{l}1356.6 \pm 25.9^{\mathrm{b}} \\
(20.33 \pm 1.07 \%)\end{array}$ & $\begin{array}{l}6672.7 \pm 178.9^{b} \\
(100 \%)\end{array}$ & $3.40 \pm 0.01^{\mathrm{d}}$ \\
\hline & 80 & $24.9 \pm 0.1^{\mathrm{a}}$ & $\begin{array}{l}1764.1 \pm 28.5^{\mathrm{b}} \\
\left(29.86 \pm 0.69^{\%}\right)\end{array}$ & $\begin{array}{l}30.9 \pm 2.7^{\mathrm{a}} \\
(0.52 \pm 0.01 \%)\end{array}$ & $\begin{array}{l}2895.9 \pm 91.5^{\mathrm{c}} \\
(49.01 \pm 0.95 \%)\end{array}$ & $\begin{array}{l}33.6 \pm 2.2^{\mathrm{b}} \\
(0.57 \pm 0.14 \%)\end{array}$ & $\begin{array}{l}1184.1 \pm 41.6^{\mathrm{c}} \\
(20.04 \pm 0.83 \%)\end{array}$ & $\begin{array}{l}5908.6 \pm 193.1^{\mathrm{c}} \\
(100 \%)\end{array}$ & $3.39 \pm 0.01^{\mathrm{d}}$ \\
\hline
\end{tabular}

The concentrations of fatty acids are expressed as mean \pm standard deviation ( $\%$ of total fatty acids) of triplicate experiments. Values in the same column that do not share the same alphabetic superscript are significantly different at $5 \%$ levels according to Duncan's multiple range tests. The basal medium was $2.0 \%$ of soluble starch as carbon source at initial pH 6.0 and incubated at $20{ }^{\circ} \mathrm{C}$ for 7 days. Same abbreviations as described as Table 1. 
docosahexaenoic acid production increased slightly with the amendment of soybean oil. In the case of $2 \%$ of soybean oil, arachidonic acid production and cell dry weight had high values at $8 \%$ of soluble starch, but they had the maximal values at $6 \%$ of glucose. A high concentration of glucose increased the osmotic pressure and decreased the efficiency of carbon source and arachidonic acid production.

The effect of glucose and soluble starch concentration with $1.0 \%$ of soybean oil supplement on biomass and PUFAs production is shown in Table 9. Biomass, $\alpha$-linolenic acid and eicosapentaenoic acid production increased with the concentration of carbon source. The yield of total PUFAs and arachidonic acid had a high value at $6 \%$ of carbon source. However, $\gamma$-linolenic acid and docosahexaenoic acid could not be detected during the cultivation. When compared the results with Table 4 , it was observed that $1.0 \%$ of soybean oil amendment increased the biomass, $\alpha$-linolenic acid, eicosapentaenoic acid and total PUFAs production, inhibited $\gamma$-linolenic acid production and reduced the degree of unsaturation. Therefore, carbon source concentration and oil supplement had stimulation effect on the PUFAs production. Appropriate concentration of oil supplement could enhance the PUFAs production in M. alpina ATCC 32222.

In conclusion, the optimum conditions for polyunsaturated fatty acids production with $M$. alipna ATCC 32222 were $10 \%$ of soluble starch as carbon source, the mixture of $\mathrm{KNO}_{3}$ and yeast extract at 2:1 (w/w) as nitrogen source at $\mathrm{C} / \mathrm{N}$ ratio 5.2-9.0, supplement with $1 \%$ of linseed oil, and incubation at $20^{\circ} \mathrm{C}$ for 3 days then shifted to $12{ }^{\circ} \mathrm{C}$ for 5 days. Each gram of carbon produced $403.4 \mathrm{mg}$ of $\alpha$-linolenic acid, $123.1 \mathrm{mg}$ of arachidonic acid, $33.6 \mathrm{mg}$ of eicosapentaenoic acid, $1.68 \mathrm{mg}$ of docosahexaenoic acid and $943.2 \mathrm{mg}$ of total PUFAs.

\section{References}

Ahern, T.J., 1983. Arachidonic acid production by the red alga Porphyridium cruentum. Biotechnol. Bioeng. 25, 1057-1070.

Bajpai, P.K., Bajpai, P., 1992. Review: arachidonic acid production by microorganisms. Biotechnol. Appl. Biochem. 15, 1-10.

Bajpai, P.K., Bajpai, P., Ward, O.P., 1991a. Arachidonic acid production by fungi. Appl. Environ. Microbiol. 57, 1255-1258.

Bajpai, P.K., Bajpai, P., Ward, O.P., 1991b. Production of arachidonic acid production by Mortierella alpina ATCC 32222. J. Indust. Microbiol. 8, 179-186.

Bajpai, P.K., Bajpai, P., Ward, O.P., 1991c. Optimization of production of docosahexaenoic acid (DHA) by Thraustochytrium aureum ATCC 34304. J. Am. Oil Chem. Soc. 68, 509-514.

Bligh, E.C., Dyer, W.J., 1959. A rapid method of total lipid extraction and purification. Can. J. Biochem. Physiol. 37, 911-917.

Braden, L.M., Caroll, K.K., 1986. Dietary polyunsaturated fat in relation to mammary carcinogenesis in rats. Lipids 21, $285-288$.
Certik, M., Shimizu, S., 1999. Review: biosynthesis and regulation of microbial polyunsaturated fatty acid production. J. Biosci. Bioeng. 87, 1-14.

Chang, C.C., Chen, H.C., 1994. Arachidonic acid production by Mortierella alpina. J. Chin. Agric. Chem. Soc. 32, 395-405.

Chen, H.C., Chang, C.C., 1994. Isolation of microbes for polyunsaturated fatty acid production. J. Chin. Agric. Chem. Soc. 32, 33-46.

Demaison, L., Moreau, D., 2002. Dietary $n-3$ polyunsaturated fatty acids and coronary heart disease-related mortality: a possible mechanism of action. Cell Mol. Life Sci. 59, 463-477.

Dyerberg, J., 1986. Linolenate-derived polyunsaturated fatty acids and prevention of atherosclerosis. Nutr. Rev. 44, 124-134.

Gil, Á., 2002. Polyunsaturated fatty acids and inflammatory diseases. Biomed. Pharmacother. 56, 388-396.

Hansson, L., Dostalek, M., 1988. Effect of culture conditions on mycelial growth and production of gamma-linolenic acid by Mortierella ramanniana. Appl. Microbiol. Biotechnol. 28, 240-246.

Jang, H.D., Lin, Y.Y., Yang, S.S., 2000. Polyunsaturated fatty acid production with Mortierella alpina by solid state fermentation. Bot. Bull. Acad. Sin. 41, 41-48.

Jang, H.D., Yang, S.S., 1998. Polyunsaturated fatty acid production with agricultural wastes by solid state fermentation. In: Sayigh, A.A.M. (Ed.), World Renewable Energy Congress. Pergamon, Oxford, pp. 1969-1972.

Jareokitmongkol, S., Shimizu, S., Yamada, H., 1993. Production of an eicosapentaenoic acid-containing oil by a $\Delta 12$ desaturase-defective mutant of Mortierella alpina IS-4. J. Am. Oil Chem. Soc. 70, 119123.

Kendrick, A., Ratledge, C., 1992. Lipids of selected molds grown for production of $\omega-3$ and $\omega-6$ polyunsaturated fatty acids. Lipids 27 , $15-24$.

Koike, Y., Cai, H.J., Higashiyama, K., Fujikawa, S., Park, E.Y., 2001. Effect of consumed carbon to nitrogen ratio on mycelial morphology and arachidonic acid production in cultures of Mortieralla alpina. J. Biosci. Bioeng. 91, 382-389.

Li, Z., Ward, O.P., 1994. Production of docosahexaenoic acid by Thraustochytrium roseum. J. Indust. Microbiol. 13, 238-241.

Lindberg, A.M., Molin, G., 1993. Effect of temperature and glucose supply on the production of polyunsaturated fatty acids by the fungus Mortierella alpina CBS 343.66 in fermentor culture. Appl. Microbiol. Biotechnol. 29, 450-455.

Park, E.Y., Koike, Y., Higashiyama, K., Fujikawa, S., Okabe, M., 1999. Effect of nitrogen source on mycelial morphology and arachidonic acid production in cultures of Mortierella alpina. J. Biosci. Bioeng. 88, 61-67.

Sajbidor, J., Dobronova, S., Certik, M., 1990. Arachidonic acid production by Mortierella sp. S-17: influence of $\mathrm{C} / \mathrm{N}$ ratio. Biotechnol. Lett. 12, 455-456.

SAS Institute, 2002. SAS User's Guide Statistics. SAS Institute Inc., Cary, NC.

Shimizu, S., Kawashima, H., Akimoto, K., Shinmen, Y., Yamada, H., 1988. Production of eicosapentaenoic acid by Mortierella fungi. J. Am. Oil Chem. Soc. 66, 342-347.

Shimizu, S., Kawashima, H., Akimoto, K., Shinmen, Y., Yamada, H., 1989. Conversion of linseed oil to an eicosapentaenoic acidcontaining oil by Mortierella alpina IS-4 at low temperature. Appl. Microbiol. Biotechnol. 32, 1-4.

Shinmen, Y., Shimizu, S., Akimoto, K., Kawasashima, H., Yamada, H., 1989. Production of arachidonic acid by Mortierella fungi. Appl. Microbiol. Biotechnol. 31, 11-16.

Totani, N., Oba, K., 1987. The filamentous fungus Mortierella alpina, high in arachidonic acid. Lipids 22, 1060-1062.

Willett, W.C., 1993. Intake of trans fatty acids and risk of coronary heart disease among women. Lancet 341, 581-585.

Yamada, H., Shimizu, S., Shinmen, Y., 1987. Production of arachidonic acid by Mortierella elongata IS-5. Agric. Biol. Chem. 51, 785-790. 
Yang, S.S., Chang, H.L., Wei, C.B., Lin, H.C., 1991. Reduce waste production in the Kjeldahl methods. J. Biomass Energy Soc. China $10,147-155$.
Yu, L.J., Qin, W.M., Lan, W.Z., Zhou, P.P., Zhu, M., 2003. Improved arachidonic acids production from the fungus Mortierella alpina by glutamate supplementation. Biores. Technol. 88, 265-268. 